\title{
Kantian nonideal theory and nuclear proliferation
}

\author{
THOMAS E. DOYLE II * \\ Department of Political Science, School of Social Science, University of California, \\ 3151 Social Science Plaza, Irvine, CA 92697-5100, USA
}

\begin{abstract}
Recent revelations of Iran's hitherto undisclosed uranium enrichment programs have once again incited western fears that Tehran seeks nuclear weapons' capability. Their fears seem motivated by more than the concern for compliance with the Nuclear Nonproliferation Treaty (NPT). Rather, they seem strongly connected to the western moral assumptions about what kind of government or people can be trusted with a nuclear arsenal. In this paper, I critically examine the western assumptions of the immorality of contemporary nuclear proliferation from an international ethical stance that otherwise might be expected to give it unequivocal support - the stance of Kantian nonideal theory. In contrast to the uses of Kant that were prominent during the Cold War, I advance and apply a sketch of a Kantian nonideal theory that specifies the conditions (although strict conditions) under which nuclear proliferation for states like Iran is morally permissible even though the NPT forbids it.
\end{abstract}

Keywords: nuclear ethics; Kantian nonideal theory

'Necessity cannot cancel morality'. Immanuel Kant (1963: 157)

Recent revelations of Iran's hitherto undisclosed uranium enrichment programs have once again incited western - and in particular American fears that Tehran seeks nuclear weapons' capability. The broad consensus of American and other western policymakers, as reflected in the public media, is that the prospect of a nuclear-armed Iran will lead to proliferation escalation among neighboring states, which in turn increases regional instability. The western reaction has been to call for negotiations in which the Iranian government would agree to forestall further uranium enrichment. Failing that, they have pushed for increased economic sanctions at United Nations Security Council (UNSC) sessions, although

* E-mail: tdoyle@uci.edu 
Russia and China have so far resisted these pressures. ${ }^{1}$ And while the Nuclear Nonproliferation Treaty (NPT) proscribes any new spread of nuclear weapons to non-nuclear states' parties, the fear of Iranian nuclear weaponization seems motivated by more than the concern for treaty compliance. Rather, it appears to be motivated strongly by western moral assumptions about what kind of government or people can be trusted with a nuclear arsenal. ${ }^{2}$

In this paper, I want to critically examine these implicit western assumptions of the immorality of contemporary nuclear proliferation from an international ethical stance that otherwise might be expected to give it unequivocal support - the stance of Kantian nonideal theory. I will argue that there are conditions (although strict conditions) where nuclear proliferation for states like Iran is morally permissible even though the NPT forbids it. In what follows, I introduce and discuss, in the first section, the relevance of Kantian nonideal theory for this issue. In the second and third sections, I briefly review the first generation of Kantian nuclear ethics that drew exclusively on Kant's ideal theory. In the fourth and fifth sections, I identify two separate resources, respectively, for a Kantian nonideal theory in order to apply and defend it in the sixth section. The seventh section is a conclusion with brief remarks on the implications of my argument.

\section{Nuclear proliferation and the relevance of Kantian nonideal moral theory}

The contemporary problem of nuclear proliferation is a paradigm case for nonideal moral theory, which is concerned with normativity in contexts where compliance with law or duty cannot be assumed or is not forthcoming (Rawls, 1971; Schapiro, 2003). The United States and its allies, for instance, regard Iran's secret enrichment programs as NPT treaty violations. In turn, many non-nuclear weapon states claim that the nuclear powers have failed to honor their NPT commitments to move in good faith toward complete nuclear disarmament (Doyle, 2009b). In partial reaction to this latter complaint, Hobbesian-leaning commentators have argued that moral obligation is binding on states only if mutual or reciprocal recognition of agreements or promises can be reasonably

1 This description represents the situation in late 2009. For a comparison of the developments during the October-November period, see Sanger (2009) and Slackman (2009).

2 Thus, it might be that German or even Turkish nuclear proliferation (although unlikely) might not arouse the same kind of concerns among American policymakers that North Korean or suspected Iranian proliferation has. 
expected. ${ }^{3}$ In their view, the kind of anarchy that constitutes the present international system does not provide such an expectation, ${ }^{4}$ and so for them the necessity principle does (and should) trump moral considerations in matters of existential threat (Sagan, 2004) or 'supreme emergencies' (Walzer, [1977] 2000) that the Iranian case seems to exemplify. If this view is correct, it follows that an international security or nuclear ethics is impractical at best and dangerous at worst.

Two compelling counterarguments, however, can be advanced to this point. First, certain prominent scholars have for some time regarded nuclear warfighting and deterrence as topics for moral scrutiny. ${ }^{5}$ During the Cold War, Nye's Nuclear Ethics (1986) was the premier monograph on this point. His main focus was American nuclear weapon policy toward the Soviet Union, and one of his main concerns was to correct what he thought was the myopia of two kinds of political moralism. He resisted idealist leaning nuclear ethics that emphasized right action independent of the common good. Nye thus rejected pacifist and Kantian nuclear ethics, along with their calls for unilateral nuclear disarmament. On the other hand, he refused to sublimate moral concerns about nuclear policy entirely to the national interest. Nye argued that individuals and states have important moral obligations to foreigners, especially to reduce the risk of harm to innocent third parties. Nye's five nuclear-ethical maxims accordingly incorporate duty-based and consequentialist approaches while emphasizing the latter: (1) selfdefense is a just but limited cause; (2) never treat nuclear weapons as normal weapons; (3) minimize harm to innocent people; (4) reduce risks of nuclear war in the near term; and (5) reduce reliance on nuclear weapons over time. ${ }^{6}$ If Nye and others across the realist-idealist continuum recognized the relevance of nuclear ethics during the Cold War, the case for its relevance to post-Cold War nuclear proliferation can be reasonably made.

${ }^{3}$ For example, Kenneth Waltz and John Mearsheimer's work implicitly advances what the late Hobbesian scholar Greg Kavka explicitly argues in his 1986 book. See Kavka (1986). The relevant discussion relates to Hobbes's claim that natural law binds in foro interno, rather than the in foro externo nature of positive law.

${ }^{4}$ The debate is if the present international system reflects Hobbesian or Lockean anarchy. In the former, moral principles do not hold at all. In the latter, some moral principles hold, but not in the way Kant would claim they do. I take the term 'Lockean anarchy' from Wendt (1999). See also, Bull (1977) and Lebow (2003).

${ }^{5}$ See, e.g. Nagel (1972); Kavka (1978); Churchill (1983); Kavka (1983); Donaldson (1985); Lee (1985); McMahan (1985); Tucker (1985).

${ }^{6}$ For an explication of these maxims, see Nye (1986), 99ff. For Nye's views against the two extremes of political moralism, see especially his chapters 4 and 5 . 
Second, it is a mistake to reduce or confine post-Cold War nonproliferation policy to matters of strategic or technological rationality. Thomas Schelling argued that 'the emphasis (of nonproliferation studies and policy) has to shift from physical denial and technology secrecy to the things that determine incentives and expectations' (quoted in Solingen, 2007). If Schelling is right, the focus of American policy should not continue to emphasize the regulation or containment of flows of nuclear materials and technologies to non-nuclear-weapon states. Instead, it should address the state- or regime-level insecurities and humiliations that provide reason for nuclear-threshold states to abandon nonproliferation commitments (see, e.g. Campbell et al., 2004; Hymans, 2006; Solingen, 2007; Doyle, 2009a, b). It should recognize that nuclear aspirant motivations are in turn framed by particular moral psychologies, both religious and secular (see, e.g. Hashmi and Lee, 2004; Hymans, 2006). The values expressed by these beliefs are themselves anchored to diverse ethical commitments about the collective good, natural and political rights, and obligations that attend international legal agreements. The sources of these conceptions are outside the domestic and international law (even if such law expresses them). Likewise, it should recognize that moral beliefs anchor the non- and counterproliferation proposals and policies put forward by countries such as the United States (Doyle, 2009a). It is thus reasonable to recognize that nuclear weapons and/or nonproliferation policy ought to not be framed by this dubious distinction between necessity and morality.

Taking a recent cue from Ken Booth (2007), I therefore contend that problems of nuclear proliferation ought to be approached as problems of political/moral theory as much as problems of strategy or technology. And, in a move that tries to correct one strand of the Cold War nuclear ethics literature, I maintain that this analysis should not rely exclusively on the principles of ideal moral theory, whose (mis)applications reinforce the perception that morality is irrelevant to politics. Instead, it should carefully consider those nonideal moral principles whose aim is to alleviate national, regional or global insecurity, and/or realize a greater measure of international justice while not insisting that each and every injustice is addressed all at once.

To say that contemporary nuclear proliferation is a paradigm case for nonideal moral theory, then, is to recognize generally how the formal is dependent upon the informal. In particular, it is to see how NPT violations can threaten to undo an important informal norm - that is, the nuclear taboo (see e.g. Bunn, 2006; Chyba et al., 2006; Bakanic, 2008). It recognizes also that morality permits states to do that which is otherwise impermissible in order to prevent greater injustices from 
happening. ${ }^{7}$ Accordingly, the most relevant question to pose is: to what extent might nonideal moral principles permit leaders of any nonnuclear weapon state to violate a voluntarily assumed legal obligation to refrain from acquiring nuclear weapons? I take it that this question is best addressed by Kantian nonideal theory.

Some might wonder 'why Kant?' Otfried Hoffe (2006) argues that Kant is the only 'great thinker' to put peace among states and peoples as a fundamental principle of philosophy. Moreover, Kant is regarded as taking an unusually rigorous moral approach. We might thus expect Kant to insist on adherence to ideal principles in all cases, entailing an unequivocal opposition to nuclear proliferation and a corresponding requirement that all states undertake unilateral and global nuclear disarmament without condition. Indeed, idealist leaning nuclear ethicists during the Cold War interpreted Kant in this way (Donaldson, 1985; Lee, 1985; McMahan, 1985). However, they overlooked those parts of Kant's writings that comprise a less than fully articulated nonideal theory, including Perpetual Peace (PP), Lectures on Ethics (LE), portions of the Metaphysics of Morals (MM) and Religion within the Limits of Reason Alone (Religion). Their mistake was to apply the more familiar and ideal elements of the Groundwork of the Metaphysics of Morals (GMM), the Critique of Practical Reason (CPR2) and Kant's late and notorious essay On the Supposed Right to Lie from Philanthropy (RTL) to the problem of nuclear deterrence in which none of the assumptions of ideal theory relevantly apply (Kant, 1785, 1793, 1795, 1797a, 1797b).

If, however, a Kantian nonideal theory can be adequately sketched and validly applied to the problem of contemporary nuclear proliferation, a significant correction can be made to the dominant accounts that over emphasize or misapply his ideal moral principles. Second, the corresponding relevance of morality for politics and political inquiry might be rehabilitated (once more). ${ }^{8}$ Third, a certain methodological parsimony is achieved. If Kantian nonideal theory concludes that Iranian nuclear proliferation is permissible under certain strict conditions, we should expect other less rigorous moral theories to be capable of similar accommodations. Finally, if the explication is successful, it would follow that some instances of nuclear proliferation are not inconsistent with Kant's ultimate vision of achieving perpetual peace.

\footnotetext{
${ }^{7}$ For a more comprehensive argument on the value of theory in nonideal circumstances, see Swift (2007).

${ }^{8}$ For a compelling argument that Hans Morgenthau rescued morality for realist IR theory, see Williams (2005).
} 


\section{Contrasting political problems for nuclear ethics}

Since its inception, the nuclear ethics literature has been primarily concerned with the morality of nuclear warfare and deterrence. Kantian approaches begin with the proscription on annihilating states in war (MM, 6:347; LE, $214)^{9}$ or engaging in the kinds of hostile military actions that undermines the possibility of constructing a durable peace (PP, 8:346). From these principles, it is not difficult to infer that Kantian theory proscribes any form of massive or extensive nuclear attack. However, since not all war-related uses of nuclear weapons entail the annihilation of states (Quester, 2006), the theory's main practical concern is with the problem of trust building between warring states. If any nuclear first-use is highly likely to trigger a cascade of nuclear retaliatory strikes, its use will almost assuredly prevent the kind of trust necessary for constructing a durable peace (Quester, 2006).

Likewise, the strategy of nuclear deterrence seems inconsistent with the duty of interstate trust building. In the 1980s, Kantians were almost unanimous in condemning nuclear deterrence, ${ }^{10}$ even though many realist leaning scholars claimed that it secured great power peace (see Sagan, 2004). However, particular instances of nuclear proliferation (e.g. French, Indian, and Pakistani) which were not linked to the Cold War superpower rivalry reveal the degree to which mistrust pervades regional rivalries (e.g. France vs. Germany in the 1950s, India vs. Pakistan in the 1990s; see Tertrais, 2003; Hymans, 2006; Smith, 2006; Way, 2007). And assuming that aspirant leaders' public policy justifications reflect their genuine (while admittedly politicized) nuclear motivations, it is reasonable to think that they believe 'right' is on their side. Consider remarks by former Iranian President Rafsanjani in 1988:

... with regard to chemical, bacteriological, and radiological weapons training, it was made very clear during the [Iraq-Iran] war that these weapons are very decisive. It was also made clear that the moral teachings of the world are not very effective when war reaches a serious stage and the world does not respect its own resolutions and closes its eyes to the violations and all the aggressions, which are committed on the battlefield. We should fully equip ourselves both in the offensive and

9 The pagination used in the parenthetical citations refers to the system developed and used for Kant's works in all their editions and translations by the Royal Prussian Academy of Sciences. In all contemporary editions, these volume and page numbers appear in the margins of the text.

${ }^{10}$ However, to the extent that John Rawls is considered to be a Kantian, his qualified acceptance of nuclear deterrence against 'outlaw states' is a notable exception (see Rawls, 1999). 
defensive use of chemical, bacteriological, and radiological weapons (quoted in Solingen, 2007: 165-166).

Rafsanjani's statement is couched in the context of the Sunni-Shi'a rivalry elevated to an international level. ${ }^{11}$ Saddam Hussein's use of chemical weapons in the Iran-Iraq War of 1980-88, in violation of the chemical weapons taboo (Price, 1997), prompted Iran's leaders to complain to the UNSC (Ansari, 2006). On their view, Saddam's actions constituted war crimes. Yet, largely due to American hostility to Iran's clerical regime following the 1979 capture of the US embassy in Tehran, the UNSC remained silent about Saddam's use of chemical weapons. That Iraq had a fledgling and illegal nuclear weapons program was common knowledge by 1988 (Solingen, 2007: Ch. 7). As a signatory to the NPT, Iranian leaders appeared to be trapped in a dilemma. If international law does not yet govern uses of certain 'tabooed' weapon systems, ${ }^{12}$ and if collective security institutions are deaf to invocations of international norms in a 'supreme emergency', the only right course of action appears to be what is legally and morally impermissible. As Rafsanjani's statement reflects, some of Iran's key leaders concluded that nuclear weapons would constitute the only effective deterrent against hostile Sunni states, Israel, and the United States. ${ }^{13}$ If international efforts to prevent Iran from continuing its uranium enrichment programs fail, it will likely be because the Ayatollah Khameini and President Ahmadinejad remain convinced that political and moral right is on their side (Doyle, 2009a: Chs. 3 and 4).

Were the Iranians to succeed in nuclear weaponization, some international security scholars believe that a proliferation cascade might engulf the Middle East, with Egypt and Saudi Arabia likely being the first in line (see, e.g. Einhorn, 2004). And even though Turkish officials resolutely deny having nuclear ambitions, a nuclear Iran makes it much more likely for Turkey to seek its own nuclear deterrent. ${ }^{14}$ One often overlooked link between the morality and the politics of these frightening possibilities can be discovered in an analysis of nationalism.

${ }^{11}$ A comprehensive account of the Sunni-Shi'a Rivalry internationalized can be found in Nasr (2007).

12 The Chemical Weapons Convention had not yet been constructed. See Price (1997).

${ }^{13}$ In making this argument, I am not claiming that the Iranian government's only or ultimate motivation to pursue nuclear weapons was to deter Iraq and other hostile Sunni neighbors.

${ }^{14}$ In an off-the-record interview I conducted with a Turkish nonproliferation official in Washington DC on 27 August 2008, Turkey's official position is that they would never have nuclear weapons ambitions. A dissenting view was expressed by an expert on Turkey, Professor Jack Kangas (currently from Johns Hopkins University) by email. This official position is challenged by Fuerth (2004) and Jack Kangas (private email correspondence). 
Nationalism is a political ideology that is framed by the moral assumptions of state-egoism. ${ }^{15}$ One is that the obligations to one's fellow citizens override those owed to foreigners. ${ }^{16}$ Another is that nation-state survival is an absolute imperative, taken to be equivalent to the (natural) right of individual survival. Since aggression is the only kind of 'crime' in international relations, all threats to nation-states must be seen as threats of aggression, that is, security threats (Walzer, [1977] 2000: 51), and nationalist moral assumptions smooth efforts at acquiring a nuclear deterrent, even if greater insecurities come afterwards. Some might think that these assumptions are invalidated or at least constrained by the pacta sunt servanda norm in international law. Still, the rebus sic stantibus provisions that inhere generally in all international treaties have the effects of conditioning pacta sunt servanda to the principle of state sovereignty. ${ }^{17}$ Thus, instead of regarding the necessity principle as conflicting with or originating outside of morality, it makes more sense to regard necessity as a central maxim of nationalist morality (which is held universally in today's international system).

Kant, however, is not a nationalist. His orientation is cosmopolitan, although his conception of a pacific federation retains the nation-state as a necessary entity of world politics. We should expect Kantian cosmopolitanism to weaken significantly the two above-mentioned assumptions of nationalist morality. We might also expect a corresponding weakening of the necessity principle, resulting in the proscription of nuclear proliferation in (almost) every case. To examine this expectation more fully, it is useful to recall the nuclear ethics debate over superpower nuclear deterrence before exploring applications to our contemporary case.

\section{Kantian ideal theory and nuclear deterrence}

In the 1980s, Kantian-leaning theorists criticized superpower nuclear deterrence based on various formulations of the Categorical Imperative (Churchill, 1983; Donaldson, 1985; Lee, 1985). One formulation states, 'So act that you use humanity, whether in your own person or in the person of any other, always at the same time as an end, and never merely

15 A detailed account of the moral underpinnings of nationalism, or the 'morality of states', is provided by Beitz ([1979] 1999).

16 This assumption regards the fellow citizen/foreigner relation as analogous to the family/ neighbor relation. Ceteris paribus, one's obligations to one's family members, is greater than to one's neighbors.

${ }^{17}$ A good introduction to pacta sunt servanda and the rebus provision is in Bederman (2006). 
as a means' (GMM 4:429). This 'Formula of Humanity' prescribes an ideal criterion for the assessment of rules for interpersonal and international conduct (Korsgaard, 1996). It acknowledges that, in daily life, the benefit of any individual's talent or labor must often accrue to others, that is, at times all individuals are treated as means for the ends of others. Even so, the Categorical Imperative requires that any use of persons must be consistent with a regard for human beings as ends in themselves, as having autonomy and dignity. This requirement is applied by asking actors to imagine in concrete cases of choice and action whether or not individuals could in principle rationally consent to the uses imposed on them from which they do not benefit. The important question to ask is whether the principles governing the uses of humanity by nuclear deterrence institutions are consistent with regarding self and others as an end and not merely as a means. I will review in turn two such principles discussed in the Cold War nuclear ethics literature - that is, the Wrongful Intentions Principle and the Principle of the Morality of Social Institutions.

The Wrongful Intentions Principle dictates that it is wrong to intend to do something that it is wrong to do. It is, for instance, wrong to murder or kidnap others and it is wrong to intend to commit those acts. Accordingly, the argument against nuclear deterrence by Kantians during the Cold War is that (1) it is wrong to use people within national defense institutions to carry out nuclear warfare and, hence, $(2)$ it is wrong to issue threats to other countries requiring the creation and administration of institutions to carry out nuclear warfare if deterrence fails (Kavka, 1978; Tucker, 1985). Now, under ideal conditions, the need for nuclear (and perhaps conventional) deterrence would not arise. But, under the kind of anarchy that corresponds to the present world system (Bull, 1977; Wendt, 1999; Lebow, 2003), where a few countries are nuclear-armed and the rest are not, it might seem that the Wrongful Intentions Principle - or the Categorical Imperative itself - is insensitive to the ethical requirement to prevent the evils of nuclear aggression. A rigorous adherence to right action and intention regardless of the outcomes might have the perverse effect of permitting evil outcomes. This is one reason advanced by realists to think that Kantian ideal moral theory is not adequately equipped to deal with the issue of nuclear security threats and the need for deterrence (Nye, 1986).

By comparison, the Principle of the Morality of Social Institutions maintains that institutional practices are justified only if they do not violate absolute rules of justice, equity, and the respect for individual rights (Lee, 1985). An effective nuclear deterrent requires a systematic arrangement of people and resources to achieve the strategic objectives of the institution and to resolve fairly conflicts that arise among its participants. However, to function effectively, any nuclear deterrence system 
must treat all involved as mere means of state policy instead of moral ends in themselves. It cannot, for instance, tolerate non-compliance by military personnel regarding orders to construct, deploy, upgrade or even use nuclear weapons in case of deterrence failure. If the defense establishment's needs are at odds with the moral autonomy of its employees, this principle dictates that the nuclear deterrence institution ought to be reformed. Otherwise, it should be abolished.

Equally important, nuclear deterrence regimes (especially under doctrines of mutually assured destruction) use foreign people as coercive instruments against their governments. During the Cold War, American and Soviet citizens became nothing more than pawns of state in the great superpower chess game, as each side held the other's populations' hostage to the threats of destruction to compel abandonment of expansion into the other's sphere of influence. Accordingly, the Principle of the Morality of Social Institutions dictates that there is no significant moral difference between superpower nuclear deterrence and kidnaping or hostage holding. Since the practice of nuclear deterrence cannot avoid violations of basic human rights, Kantians during the Cold War believed that it was always impermissible.

On the face of it, applications of the Wrongful Intentions Principle and the Principle of the Morality of Social Institutions to instances of recent nuclear proliferation suggest a continuity of moral assessment across both world times. ${ }^{18}$ This is to say, Kantian ideal theory regards both Cold War and contemporary nuclear deterrence regimes to be motivated by wrongful intentions and characterized by impermissible uses of countrymen and foreign people. Thus, despite the significant political and strategic differences between these two eras of deterrence that might ordinarily affect our considered moral judgments, a Kantian ideal assessment regards them as irrelevant.

Now, a realist critique of the Principle of the Morality of Social Institutions might echo the criticism of the Wrongful Intentions Principle. The requirement to treat all involved persons according to absolute rules of human rights, justice, and equity in all circumstances might (perversely) permit greater evil than a less righteous but more prudent policy. Kantian leaning ethicists, however, are not wont to convert to realism or consequentialism, for a compelling argument remains that the moral rightness and wrongness of actions is a feature of the action itself. Yet, the realist still urges that the Kantian disregard for consequences (e.g. do what is right even if the world should come to an end) makes it a dangerous ethic for policymaking.

${ }^{18}$ I borrow the term 'world times' from Solingen (2007). 
I contend that this realist critique is based on an overly restrictive reading of Kant. Rather than taking our cues about the morality of contemporary nuclear proliferation and deterrence from Kantian ideal theory, I propose to draw on Kant's discussion of self-defense in LE, MM, and PP, and in the following section on one formulation of the Categorical Imperative in GMM whose nonideal elements have been overlooked by Kantian nuclear ethicists.

\section{Resources for a Kantian nonideal approach to nuclear proliferation}

Kant's views on self-defense may be divided into two categories: selfdefense of individual persons (from which we may draw tentative 'domestic analogies' for national defense) and national defense under the kind of anarchy that corresponds to today's world.

\section{Individual self-defense}

I read Kant as maintaining that every individual is morally obliged to protect her own life and autonomy. ${ }^{19}$ This reading is culled from two passages in LE, where Kant says:

1. 'The rule of morality, which takes precedence of all rules of reflective prudence, commands apodeictically and categorically that we must observe our duties to ourselves; ... Man is free to dispose of his (occupational) condition but not of his person; he himself is an end and not a means .... Our duties towards ourselves constitute the supreme condition and the principle of all morality; for moral worth is the worth of the person as such'. (LE, 120-121)

2. 'There is nothing more sacred in the wide world than the rights of others. They are inviolable. Woe unto him who trespasses upon the right of another and tramples it underfoot! His right should be his security; it should be stronger than any shield or fortress'. (LE, 193-194)

In these passages, Kant presupposes nonideal conditions and simultaneously looks forward to the ideal Formula of Humanity. The duty to treat oneself as an end and not merely as a means comprises the necessary and sufficient grounds to protect oneself against hostile neighbors and

19 Two points: (1) Kant also argues that the continuation of life under non-autonomous conditions may not be worth it. 'The moral life is at an end if it is not longer in keeping with the dignity of humanity' (LE, 156). This implies that the self-defense right is conditioned by the moral honor or virtue to which it aims to realize. (2) Expressing the problem in this way seems to strengthen the notion that the necessity principle is in fact a nonideal moral principle. 
criminal aggressors. Yet, for Kant the ultimate condition of personal security is found in the sacred respect for rights that each individual should exhibit toward all others. Self defense therefore is best understood as a reciprocal or mutual relation. When expressed as a speech act, it signifies the supreme value of human rights as that which ought never to be compromised.

In the Critique of Practical Reason, Kant takes a slightly different angle. $\mathrm{He}$ indicates that personal security is ideally a matter of law enforcement over which the state has absolute coercive authority. But, state authorities are not always capable of protecting individuals from criminal activity. This incapacity partly constitutes the nonideal conditions with which we are concerned. In a section titled 'The right of necessity', Kant recognizes the right to use lethal force against a 'wrongful assailant of [one's] life' (MM, 6: 235). Kant implies that lethal self-defense is permissible only when one's life is directly attacked by another, and his position here is no different than Hobbes ([1651] 1968). However, Kant's placement of necessity into the Doctrine of Right, which itself is part of his ethics, is significantly different from the Hobbes's conception of necessity, and it helps us understand why Kant claimed that necessity 'cannot cancel morality'(Kant, 1963: 157). If morality is not canceled by necessity, then it is possible that necessity itself a nonideal moral principle.

Of equal interest is Kant's justification of lying as a method of selfdefense. Kant permits this kind of deception under three conditions: if the criminal uses coercion against the victim, if what rightly belongs to the victim is used against her, and if her remaining silent cannot effect her escape or rescue (LE, 227-228; Korsgaard, 1996: Ch. 5). Lying under these conditions is not committing an injustice to a criminal aggressor; it is merely treating him according to a general law of reciprocity. Admittedly, Kant believes that lying even in these circumstances is a violation of the civil condition since it puts the rights of humanity at risk. But, it is easy to overlook a subtle distinction in Kant's discussion, namely the difference between putting the rights of humanity at risk and violating them. Thus, while it is absolutely forbidden to violate the rights of humanity, it might be necessary sometimes to put them at risk.

One might object here that the weight of Kant's other writings on lying challenges the case I am trying to build. Kant notoriously argued in more than one place that a 'well-meant lie' is a violation of legal duty, and it violates moral duty by bringing about the condition that declarations (of the type advanced by the lie) are in general not believed.

... if you by a lie prevented someone just now bent on murder from committing the deed, then you are legally accountable for all the 
consequences that might arise from it. But if you have kept strictly to the truth, then public justice can hold nothing against you, whatever the unforeseen consequences might be. (RTL, 8: 426-427)

Kant imagines a case in which a well-meaning friend tries to protect an intended victim by telling a lie to an assailant, and yet unanticipated turns of events make it to where the assailant finds and murders the victim (who had left the house and gone in the direction the murderer took by virtue of the friend's directions). For Kant, the friend can be held responsible in court for the unintended death of the victim, which his lie helped to cause. Kant argues that only by utter truthfulness could this friend be absolved from any responsibility for the victim's death.

Yet, it must be emphasized that Kant's example in RTL is qualitatively different from that cited in LE. For Kant, a well-meaning lie used in the defense of another has different implications for moral and legal responsibility than one told in self-defense. The latter kind of lie, if the criminal aggressor believes it, deters and prevents wrongdoing against oneself. The result is that one's rights are protected without the need to violate the aggressor's rights. The former kind of lie, if believed, does not necessarily prevent wrongdoing and most likely merely delays it. In other words, the former kind of lie does not necessarily result in the securing of human rights. Admittedly, critics might still find Kant's view on the former kind of lie objectionable, for it means that altruistic Germans that lied to save Jews in WWII are somehow guilty of violating absolute moral or legal requirements. And I am inclined to agree with the critics on this matter, but Kant's argument against well-meaning lies in defense of another is not relevant to the matter of lies told in personal self-defense. And it is this kind of lie that matters for domestic analogies regarding the nuclear self-defense of states.

Unfortunately, the fact of nonideal conditions makes it impossible to sometimes avoid putting humanity's rights at risk in the pursuit of legitimate self-defense. This is just what any nonideal principle is constructed to do, to help actors facing injustice and without recourse to lawful solutions to conform their conduct as closely to the moral ideal as is practically possible. A corollary maxim thus might be formulated: use only those modes of self-defense that remain within the bounds of reciprocity as conditioned by a wrongdoer's offense. ${ }^{20}$

My analysis so far shows that Kant permits an individual's right of selfdefense to include actions that avoid or deflect aggression, while lethal

${ }^{20}$ For additional argument in support of the claim that even well-meaning lies in other people's defense are consistent with the Formula of Universal Law, see Nell (1975). Note: Onora Nell has gone by Onora O’Neill since the 1980s. 
acts are permissible only if another poses an immediate survival threat. In contrast, Kant proscribes all acts of private vengeance and enmity in the name of self-defense, although individuals retain the right to hate those who act hatefully against them (LE, 209-214). For Kant, enmity is 'an express disposition to do harm to another' that is conceptually distinct from the attitude of hatred, and vengeance is a personal act of enmity that seeks to repay evil for evil outside of legal authorization. Neither enmity nor vengeance is consistent with one's duties to oneself or others, and in some cases they count as aggression itself. Put slightly different, enmity and vengeance are inconsistent with the principle of reciprocity as conditioned by the wrongdoer's offense, while expressing hatred is not inconsistent.

\section{National defense under anarchy conditions}

Kantian nonideal theory recognizes that conceptions of and commitments to national interest drive national security policy in today's world. But, it should be emphasized that Kant's nonideal theory is a bridge between this world and that world governed by moral legitimacy and public right. Just as Kant regarded indirect duties (e.g. to treat animals humanely) as tutors in the service of ideal duties (e.g. treating humans humanely), Kant regards the duties of public right that nation-states bear as a condition necessary to the construction of long-term security and peace.

Kant contends that an international state of nature is a mutual relation of constant war, which necessarily constitutes a wrongful condition (MM, 6:343; PP, 8:349). Each country has a self-defense right, which is identical to the right to go to war (MM, 6:346). Even so, Kant disagrees with Clausewitz that the logic of warfare is that of unlimited violence (Walzer, [1977] 2000: 23). Warfare must always leave open the possibility of leaving the state of nature and entering the rightful condition of a pacific federation (MM, 6:347). Thus, Kant permits standing armies as a temporary instrument to deter or respond proportionally to aggression (PP, $8: 345)$. On the other hand, no hostile act during war is morally permissible (or even instrumentally rational!) if it undermines the trust necessary to establish a future peace (PP, 8:346). ${ }^{21}$ It is this tension between permitting the existence of armed forces for deterrence and the requirement

\footnotetext{
${ }^{21}$ It is important to note, from a historical viewpoint, that the United States use of atomic weapons on Japan in WWII did not preclude a long peace between them, nor did the threats of mutual assured destruction preclude the significant peace between the United States, Russia, and China following the Fall of the Berlin Wall. Thus, we arrive at a counterintuitive hypothesis - that atomic mass destruction is not sufficiently hostile to necessitate its absolute
} 
to forego hostile actions that undermines future trust that directly relates to our current inquiry. Since a (vastly) weaker or disadvantaged state might not be capable of effective defense without recourse to deception, we want to know if, for Kant, permissible uses of deception include the issuance of nuclear deterrence threats where the credibility of the bluff depends upon the acquisition of nuclear weapons.

\section{The Formula of Universal Law}

Kant's first formulation of the Categorical Imperative - that is, the Formula of Universal Law says: 'Act only in accordance with that maxim [or moral rule] through which you can at the same time will that it become a universal law' (GMM, 4:421). A few lines later, Kant refines this formula to say 'act as if the maxim of your action were to become by your will a universal law of nature', where 'nature' is understood in its most general sense to include the physical and social worlds (GMM, 4:422). For Kant, then, the Formula of Universal Law is used to determine if a maxim (i.e. a proposed moral rule) could regulate our conduct without contradiction or exception. Of the three formulations of the Categorical Imperative in GMM, this one is the nonideal formulation (Nell, 1975: Ch. 4; Korsgaard, 1996: Ch. 3). Accordingly, it is by this formulation that maxims regarding national defense by means of deception are to be examined.

Earlier in GMM, Kant had contrasted the 'counsels of prudence', regarded by IR realists as the most appropriate method of policy formation and regulation, and the commands of (moral) law that are categorical, unconditional and necessary to obey ${ }^{22}$ (4: 415-420). For Kant, counsels of prudence 'cannot ... command at all' (4: 418) because their validity depends upon the desirability of the objectives, the capabilities of the actors involved, and other such contingencies. In contrast, commands of (moral) law 'must be obeyed, that is, must be followed even against inclination' or advantage (4: 416-417). Kant elaborates in some detail:

... the categorical imperative alone has the tenor of a practical law; all the others can indeed be called principles of will but not laws, since what it is necessary to do merely for achieving a discretionary purpose can be regarded as in itself contingent and we can always be released from the precept if we give up the purpose; on the contrary, the unconditional

proscription on Kantian terms. What this means for a Kantian analysis of nuclear deterrence is what I try to tackle in the latter part of the paper.

22 Of course, the question over if an actor actually obeys an unconditional command of law is a separate issue. 
command leaves the will no discretion with respect to the opposite, so that it alone brings with it that necessity which we require of a law. (4: 420)

The central point here is the difference between contingent and necessary moral ends. We may be released from any 'command' of prudence if we give up on the project or objective. To give up on a project or objective is to tacitly accept that it was not morally necessary. However, we may never rightfully give up on that which, on Kant's view, reason commands unconditionally, which is to say 'commands universally'. Thus, Kant maintains that each individual person should always preserve their physical existence even if it seems that death is preferable, or speak truthfully to others even if great inconvenience can be avoided by lying (4: 423). In short, the Formula of Universal Law reveals that a maxim that cannot be willed to become a universal law of nature is inconsistent with moral right and duty in as much as it entails a formal contradiction: the actor wills both that (a) the maxim ought always to be followed and (b) the maxim ought to be followed only some of the time.

Now, one could admit that (a) and (b) are contradictory but still wonder 'Where does (a) come from, and why should any actor be committed to it?' Given the points made above on the contingency of prudence and the necessity of rational morality, we can infer that (a) originates in the imperative's form - that any maxim that passes its test is one that ought always to be followed by its addressees. In addition, the Formula of Universal Law makes any maxim that passes its test binding on all relevant actors. This means that, even if a solitary actor proposed the maxim for herself alone, the universality condition makes it authoritative for any other similarly situated actor insofar as it is regarded as a 'universal law of nature'. It is for these reasons that any maxim of the form of (b) does not pass the test.

To the best of my knowledge, previous scholarship in Kantian nuclear ethics assumes that the ideal/nonideal theoretic distinction maps onto that between reason and prudence (see e.g. Churchill, 1983; Donaldson, 1985; Lee, 1985; McMahan, 1985; Tucker, 1985). Accordingly, the Formula of Universal Law has been taken as a principle of Kantian ideal theory. I believe this move assumption is mistaken. Christine Korsgaard convincingly argues that Kantian moral theory is a 'double-level' theory:

The formulas for Humanity and the Kingdom of Ends provide the ideal, which governs our daily conduct. They are not applicable in contexts of evil, which can require that we depart from the ideal in order to secure the greatest instantiation of justice that we can. The formula of Universal Law provides the point at which morality is uncompromising (Korsgaard, 1996: 154). 
The Formula of Universal Law therefore recognizes the fact of noncompliance with moral, civil, and international legal requirements, and it draws a line beyond which no claim of exclusion or suspension from duty is justified. For, if morality is to be action guiding at all (Nell, 1975), it cannot be so only in contexts of relatively good compliance with norms.

Having now explicated the Formula of Universal Law in some detail, the question is how it might apply to Kant's remarks on lying in selfdefense and specifically on the permissibility of nuclear deterrence lies for national defense. Recall that Kant acknowledged that lying in self-defense is always a threat to the moral order. No one could rationally will that all persons everywhere be permitted or required to tell falsehoods, for the integrity of social interaction and especially contractual relations (RTL, 8: 245-246) would unravel if the duty to be truthful was abandoned. Thus, it is impossible to prescribe universally that (a') it is always acceptable to lie to gain advantage and ( $\left.b^{\prime}\right)$ it is never acceptable for another to lie when they are advantaged and I suffer loss. However, in nonideal conditions it could be rationally willed that every individual be permitted to lie to prevent their autonomy rights from being trod underfoot by liars and assailants (Nell, 1975: Ch. 5). If lying to a lying assailant does him no injustice, morality is not contradicted by the nonideal rule that permits deception in those instances while proscribing it generally.

Contrast the foregoing with the inconsistency of any maxim that prescribes the necessity of assured destruction as a form of nuclear 'selfdefense'. To imagine such a maxim becoming universal law is to imagine that no contradiction exists between ( $\mathrm{a}$ ") always permitting the use of nuclear weapons on another country's entire population in response to an attack and (b") proscribing the same by any other state in self-defense against one's own cities. But, the contradiction is plain. The Kantian universality test restricts the scope of nonideal principles to those that are impartial. Yet, a" is not something that can be affirmed simultaneously with b”.

\section{Applying Kantian nonideal theory to contemporary nuclear proliferation}

As I read Kant, a state's right to go to war entails the right to threaten to go to war. It follows, first of all, that officials have the right to form the corresponding intentions necessary to wage or threaten war. Second, they have the right to acquire the armaments needed for warfare or for making their threats credible. But, living in the 18th century, Kant could not have conceived that states would become capable of creating, stockpiling, or using nuclear weapons to prevent or respond to the kind of aggression experienced in the 20th and 21st centuries. Yet, if it can be shown that 
Kantian nonideal theory permits nuclear deterrence under certain conditions, the prima facie right to acquire nuclear weapons can also be shown.

To make the following discussion appropriately general and yet applicable to contemporary cases (e.g. Iran), I shall refer to two hypothetical states that coexist in the kind of anarchy that corresponds to today's international system. Let us call them 'Aspirant' and 'Rival'. Aspirant is a nuclear threshold state in a 'troubled' or insecure region and Rival is their antagonist that also has nuclear weapons aspirations (e.g. Syria), actually has nuclear weapons (e.g. the United States), or is allied with an economically developed and nuclear-armed state (e.g. Israel). For our purposes, Aspirant and Rival are signatories to the NPT. Admittedly, Aspirant's pursuit of nuclear weapons by itself says nothing explicitly about their intentions. But this does not mean that Aspirant's intentions are entirely opaque, especially if their pursuits are accompanied by publicly advanced reasons or threats against Rival. A valid Kantian assessment of Aspirant's nuclear pursuits therefore depends a great deal (but not exclusively) on the intentions that motivate their deterrence threats against Rival.

It is important at this point to distinguish two kinds of target for Aspirant's deterrent threats: Rival's military centers and government/ population centers. It is equally important to distinguish two kinds of corresponding intentions: an intention to carry out the threat should deterrence fail and one to never carry out the threat. Table 1 depicts the conceptual territory of targets and intentions:

Each number in Table 1 specifies a policy option for Aspirant that pairs a threat target with a threat intention. Option (1) pairs the reprisal threat against military centers with the intention to carry it out if deterrence fails. Option (2) pairs the threat against military centers with the intention to never carry it out. Option (3) pairs the threat against population/ government centers with the intention never to carry out the threat. And option (4) pairs the threat against population/government centers with the intention to carry it out. One should note that Table 1 does not relate a game theoretic matrix of choices with associated payoffs. Its purpose is to map the range of policy options available to Aspirant. Specifically,

Table 1. Range of policy options - deterrence targets and intentions

\begin{tabular}{lcc}
\hline \hline Threaten/intentions & Carry out & Never carry out \\
\hline Military centers & 1 & 2 \\
Population/government centers & 4 & 3 \\
\hline \hline
\end{tabular}


Aspirant can undertake any of the four options individually or a limited set of combined options: (1) and (4), (2) and (3), or (2) and (4). Two combined options - (1) and (2) and (3) and (4) - are excluded inasmuch as they are contradictory and could not be implemented at the same time. And, one combined option - (1) and (3) - is equivalent to (1) only.

Now, an intention to carry out nuclear deterrent threats in the context of deterrence failure is an intention to engage in nuclear war. Analysis of this category obviates the need to apply the Kantian view on lying in selfdefense, since Aspirant means to make good on retaliatory threats. Let us evaluate the only three options. The first is Aspirant's policy to carry out deterrent threats on military and population/government centers. This choice is tantamount to desiring Rival's annihilation, which violates the doctrine of right (MM, 6:235) as well as the nonideal proscriptions against enmity and vengeance in LE. On Kantian terms, the Formula of Universal Law would not pass any maxim that corresponds to a policy of comprehensive nuclear reprisal. To see why, let us assess two varied formulations.

One might be called a maxim of overkill: 'In all instances of nuclear deterrence failure, the victim of aggression must retaliate by means of nuclear strikes against the aggressor's military, political, and population centers'. This maxim is easily rejected, for it is the clearest case of state annihilation, that Kant prohibits absolutely. However, it might be compared to a maxim of strict nuclear reciprocity: 'In all instances of nuclear first strikes, it is the duty of the victim to retaliate in kind'. One of the most challenging cases would be where Aspirant suffers a nuclear first strike on one military center and one industrial center. The maxim dictates that the retaliatory nuclear strike must hit one of Rival's military and industrial centers. In many cases, acting on this maxim falls significantly short of state annihilation, even though it probably involves high levels of civilian casualties. It might even promote the re-establishment of deterrence in as much as it reinforces the expectation that nuclear escalation will be punished and de-escalation will be rewarded (Gauthier, 1984). However, a Kantian assessment of this maxim is largely independent of these consequentialist concerns. Recall that the Formula of Universal Law draws an uncompromising bottom line where even Rival's wrongdoing cannot justify Aspirant's maxim of strict nuclear reciprocity. The indiscriminate destruction of human life, even when Aspirant and Rival destroy only one military and industrial center apiece, cannot be willed as a universal law of nature. And if Aspirant really intended to allow strict nuclear reciprocity only for themselves and no one else, such partiality cannot be reconciled with the Formula of Universal Law's requirement to transform a maxim into a law that obligates all relevant actors. 
The same analysis applies to any policy of carrying out deterrent threats solely against population/government centers. However, for Aspirant to carry out deterrent threats solely against military centers seems prima facie consistent with Kant's view on the right of national defense, and it parallels some applications of just war theory on the problem of limited nuclear warfighting (Ramsey, 1962; Orend, 2000). Once acquired, a lowyield nuclear device might annihilate one or more of Rival's army divisions, naval task forces, or air-force bases, severely crippling its capacity to continue to aggress. More importantly, a maxim that corresponds to this intention appears to pass the universality test. Aspirant could in principle assent to a rule that permits all nuclear-armed states to threaten and carry out exclusively counterforce nuclear reprisals, much in the same way that nationalist morality permits all states to use conventional force in selfdefense. $^{23}$ This isn't to say that Rival can read off Aspirant's intentions from its nuclear procurement behavior. And this is not to say that in the process of nuclear miniaturization required to produce these weapons that Aspirant might not retain its larger nuclear devices. It is to say, though, that Aspirant's maxim on this point can be imagined without formal contradiction. Moreover, were Aspirant to miniaturize its arsenal and then verifiably decommission or destroy its larger devices, Rival might come to behave that Aspirant had abandoned any policy of mutually assured destruction in favor of a policy of severely limited counterforce warfare.

There are, however, significant constraints on this nuclear defense right. Intending to carry out threats against counterforce targets would be impermissible on Kantian nonideal principles if they led to countervalue strikes or a counterforce escalation that entailed massive collateral damage. In conventional warfighting, the just-war doctrine of double effect permits unintended and limited killing of noncombatants on grounds of military necessity. However, at some point an escalation of counterforce strikes cannot avoid ruining the surrounding eco-systems and in turn injuring or destroying innocent human life. It would then be false to claim that Aspirant only intended to do good by undertaking counterforce strikes of this kind. It would also be false to claim these counterforce strikes were necessary evils, and that the goodness of the outcome made the cost of the counterforce strikes worth it (Orend, 2000: 164).

Barring these prohibiting conditions, though, my reading of Kantian nonideal theory suggests that Aspirant's choice to carry out deterrent threats strictly against military centers of Rival is permissible. Given the

23 Admittedly, using nuclear weapons in this way violates a central maxim of Joseph Nye's nuclear ethics - to never treat nuclear weapons as ordinary weapons. 
special nature of the nuclear threat environment, Kantian nonideal theory permits Aspirant to do all that is consistent with the reciprocity corollary to defend itself. And if Aspirant truly faces a nuclear threat from Rival, their NPT commitments do not clearly over-ride their national defense obligations. Indeed, the inclusion of Article X into the NPT is evidence that states parties are already committed to this position.

What of the other policy options? The most salient options are that Aspirant might levy deterrent threats against Rival's military or/and their government and population centers but never intend to actually strike any target or never intend to strike any population or government centers. The important practical difference between this set of possibilities and those already considered is that Aspirant expresses a threat against both military and government/population centers. The important moral difference is that this latter set of options embodies the intent to deceive. What moral assessments now follow on the basis of Kant's views on lying in self-defense and the Formula of Universal Law?

First, we recall that the purpose of lying to criminal aggressors is to deflect or avoid aggression and that lying to liars or assailants is not an injustice to them. If, for instance, North Korea's nuclear threats are bluffs, they nevertheless are regarded by some to have helped dissuade America (i.e. the Bush Administration) from launching anticipatory military strikes against Pyonyang (Smith, 2006: Ch. 4). This kind of deterrent threat by itself then appears at first glance to be permissible within the bounds of reciprocity. That said, the lie told to the criminal aggressor in Kant's example does not include a threat of harm. In contrast, the promise of harm that the threat conveys - which is an attitude Aspirant intends to cultivate even though he does not actually intend to carry out the threat - activates Rival's hostility and the corresponding difficulty in trust building. Such threats are inconsistent with Kant's nonideal Sixth Preliminary Article that proscribes acts of hostility 'as would have to make mutual trust impossible during a future peace ...' (PP, 8: 346). In plain terms, a persuasive nuclear deterrent threat that Aspirant secretly intends to never carry out still inflicts a determinate harm that mere deflection or avoidance of aggression does not, namely the construction of an existential insecurity in the threatened state and, to the extent the threat is made public, the creation of existential fear among people that are 'ends in themselves'. ${ }^{24}$

Still, given the kind of anarchy that is in today's world, it would be a mistake to think that Kant would absolutely forbid the practice of using

\footnotetext{
${ }^{24}$ Yet, this judgment is not a necessary one, as the history between United States and Japan suggests.
} 
deception in nuclear deterrent threats. Assuming that Rival previously uttered a credible existential threat to Aspirant, and assuming that Aspirant is not an ally of a country with a nuclear umbrella of its own, a nuclear deterrent lie told to Rival is not unjust, even if it generally increases the tendency to not believe statements of this kind. A credible deterrent lie prevents or deflects aggression without causing further injury. In the same fashion, the reciprocity corollary advanced in fourth Section establishes the possibility that, given a world of nuclear-armed states that have already instituted nuclear deterrent regimes and have made hostile threats of their own, Aspirant might reasonably conclude that advancing persuasive nuclear deterrent lies is necessary for national defense. And to establish the credibility of those threats, it would be morally permissible for Aspirant to acquire nuclear weapons even though the NPT forbids it.

\section{Conclusion}

Kant believed that necessity could not cancel morality. This is because necessity is itself a nonideal moral principle. However, necessity does not justify any indiscriminate and disproportionate use of force in the name of self-defense. Necessity is not amoral nationalism run amok. Kantian nonideal theory permits states to advance and carry out a narrowly aimed deterrent nuclear threat against counterforce targets that would match the degree to which aggression has been or is likely to be committed, but proscribes deterrent threats of mass destruction or annihilation. To carry out these latter threats would violate the ideal and nonideal requirements of human dignity and reciprocity. More interestingly, Kantian nonideal theory conditionally permits the practice of issuing threats of nuclear reprisal that are never intended to be carried out. It follows that Kantian nonideal theory cannot absolutely proscribe Aspirant's nuclear weapons acquisitions as a means of deterring Rival, but the conditions under which Aspirant may acquire them are significantly restricted.

The implications of these conclusions reach into both theory and policy. I cannot discuss any of these at length at this point, and most are worthy of extended examination in their own right. I shall therefore close by briefly discussing three implications. First, I believe this analysis corrects the tendency among Kantian leaning nuclear ethicists to draw exclusively from his ideal theory. If I am right, Kantian nonideal theory accommodates realist concerns without converting to full-blooded realism or moral consequentialism. It retains the emphasis on moral autonomy and the rightness of action independent of mere consequence. More to the point, Kantian nonideal assessments provide the scope conditions for justified nuclear proliferation while requiring both Aspirant and Rival to 
exercise their rights consistent with reciprocity and the duty to achieve perpetual peace.

Second, my analysis reinforces the argument against IR realism's attempt to divorce the concepts of necessity and morality. On my view, the necessity principle is a nonideal moral principle because it affirms the pre-legal and historical conviction that bonds of national existence have intrinsic value, that obligations towards fellow citizens can often take precedence over the obligations to strangers when these conflict, and that national security is a necessary condition for the realization of other goods. It also shows that Kantian nonideal theory can meaningfully apply the necessity principle properly bounded by reciprocity to conditions of nuclear threat. That Kant incorporates the necessity principle into his nonideal theory also strengthens the notion that morality and politics are intimately related.

Finally, in terms of policymaking my analysis implies that we ought to not uncritically assume that all instances of contemporary nuclear proliferation are morally unjustified. It is yet to be determined whether an Iranian (or, hypothetically, an Egyptian, Saudi, or Turkish) nuclear weapons program is justified; the point is that it might be justified on Kantian nonideal grounds. Were the entire justification for an Iranian policy of acquiring nuclear weapons to rest on, say, Islamic ethics, Western leaders might conveniently dismiss it. However, that this proposal finds conditional support in Kantian nonideal theory casts Western policymakers into a familiar yet challenging normative context that they ought not to dismiss too readily. Therefore, as Kant had recommended to the European monarchs of old $(8: 369-370)$, it seems to me that the nonproliferation policy community would do well to consult with nuclear ethicists, just as the medical community has done regarding the critical care of patients.

\section{Acknowledgments}

The author thanks the following individuals for their helpful comments on previous drafts of this paper and in general for their ideas and support: Aaron James, Etel Solingen, Alexander Wendt, Duncan Snidal and three anonymous referees at International Theory. The author takes full responsibility for any remaining errors.

\section{References}

Ansari, A.M. (2006), Confronting Iran: The Failure of American Foreign Policy and the Next Great Conflict in the Middle East, New York, NY, USA: Basic Books. 
Bakanic, E.D. (2008), 'The End of Japan's Nuclear Taboo'. Bulletin of the Atomic Scientists, retrieved 06/09/2008 from http://www.thebulletin.org/node/3105

Bederman, D.J. (2006), International Law Frameworks, 2nd edn., New York, NY, USA: Thomson West.

Beitz, C.R. [1979] (1999), Political Theory and International Relations, with a New Afterword by the Author, Princeton, NJ, USA: Princeton University Press.

Booth, K. (2007), Theory of World Security, Cambridge Studies in International Relations. Cambridge, UK: Cambridge University Press.

Bull, H. (1977), Anarchical Society, London, UK: Macmillan.

Bunn, G. (2006), 'The nuclear nonproliferation regime and its history', in G. Bunn and C.F. Chyba (eds), US Nuclear Weapons Policy: Confronting Today's Threats, Washington, DC, USA: Brookings Institution Press.

Campbell, K.M., R.J. Einhorn and M.B. Reiss (eds) (2004), The Nuclear Tipping Point: Why States Reconsider Their Nuclear Choices, Washington, DC, USA: Brookings Institute Press.

Churchill, R.P. (1983), 'Nuclear arms as a philosophical and moral issue', Annals of the American Academy of Political and Social Science 469: 46-57.

Chyba, C.F., C. Braun and G. Bunn (2006), 'New challenges to the nonproliferation regime', in G. Bunn and C.F. Chyba (eds), US Nuclear Weapons Policy: Confronting Today's Threats, Washington, DC, USA: Brookings Institution Press.

Donaldson, T. (1985), 'Nuclear deterrence and self defense', Ethics 95(3): 537-548.

Doyle, T.E. (2009a), 'Moral dilemmas: acquiring nuclear weapons in the second nuclear age'. Unpublished doctoral dissertation. University of California, Irvine.

- (2009b), 'The moral implications of the subversion of the nonproliferation treaty regime', Ethics and Global Politics 2(2): 131-154.

Einhorn, R.J. (2004), 'Will the abstainers reconsider? Focusing on individual cases', in K.M. Campbell, R.J. Einhorn and M.B. Reiss (eds), The Nuclear Tipping Point: Why States Reconsider Their Nuclear Choices, Washington, DC, USA: Brookings Institution Press.

Fuerth, L. (2004), 'Turkey: nuclear choices amongst dangerous neighbors', in K.M. Campbell, R.J. Einhorn, and M.B. Reiss (eds), The Nuclear Tipping Point: Why States Reconsider Their Nuclear Choices, Washington, DC, USA: Brookings Institution Press.

Gauthier, D. (1984), 'Deterrence, maximization, and rationality', Ethics 94(3): 474-495.

Hashmi, S.H. and S.P. Lee (eds) (2004), Ethics and Weapons of Mass Destruction: Religious and Secular Perspectives, Cambridge UK: Cambridge University Press.

Hobbes, T. [1651] (1968), Leviathan. Ed and introd by C. B. Macpherson. Baltimore, Md, USA: Penguin.

Hoffe, O. (2006), Kant's Cosmopolitan Theory of Law and Peace, Alexandra Newton. Cambridge UK: Cambridge University Press.

Hymans, J.E.C. (2006), The Psychology of Nuclear Proliferation: Identity, Emotions, and Foreign Policy, Cambridge, UK: Cambridge University Press.

Kant, I. (1785), 'Groundwork of the metaphysics of morals', in M.J. Gregor (ed.), The Cambridge Edition of the Works of Immanuel Kant: Practical Philosophy, Cambridge, UK: Cambridge University Press.

- (1793), 'Religion within the boundaries of mere reason', in A.W. Wood and G.D. Giovanni (eds), The Cambridge Edition of the Works of Immanuel Kant: Religion and Rational Theology, Cambridge, UK: Cambridge University Press, pp. 39-216.

— (1795), 'Towards perpetual peace', in M.J. Gregor (ed.), The Cambridge Edition of the Works of Immanuel Kant: Practical Philosophy, Cambridge, UK: Cambridge University Press, pp. 311-352. 
— (1797a), 'The metaphysics of morals', in M.J. Gregor (ed.), The Cambridge Edition of the Works of Immanuel Kant: Practical Philosophy, Cambridge, UK: Cambridge University Press, pp. 353-604.

— (1797b), 'On a supposed right to lie from philanthropy', in trans. M.J. Gregor and A. Wood (eds), The Cambridge Edition of the Works of Immanuel Kant: Practical Philosophy, Cambridge, UK: Cambridge University Press.

Kant, I. and Louis Infield trans. (1963), Lectures on Ethics, New York and Evanston: Harper \&

Row, Publishers, p.157.

Kavka, G.S. (1978), 'Some paradoxes of deterrence', Journal of Philosophy 75(6): 285-302.

_ (1983), 'Doubts about unilateral disarmament', Philosophy and Public Affairs 12(3): 255-260.

(1986), Hobbesian Moral and Political Theory, Princeton, NJ, USA: Princeton University

Press. pp. 349-358.

Korsgaard, C. (1996), Creating the Kingdom of Ends, Cambridge, UK: Cambridge University Press.

Lebow, R.N. (2003), The Tragic View of Politics: Ethics, Interests and Orders, Cambridge, UK: Cambridge University Press.

Lee, S.P. (1985), 'The morality of nuclear deterrence: hostage holding and consequences', Ethics 95(4): 549-566.

McMahan, J. (1985), 'Deterrence and deontology', Ethics 95(3): 517-536.

Nasr, V. (2007), The Shia Revival: How Conflicts Within Islam Will Shape the Future. With a New Afterword, New York, USA: W. W. Norton \& Company.

Nell, O. (1975), Acting on Principle: An Essay on Kantian Ethics, New York, USA: Columbia University Press.

Nye, J.S. (1986), Nuclear Ethics, New York, USA: The Free Press.

Orend, B. (2000), War and International Justice: a Kantian Perspective, Waterloo, Ontario, Canada: Wilfrid Laurier University Press.

Price, R.M. (1997), The Chemical Weapons Taboo, Ithaca, NY, USA: Cornell University Press. Quester, G. (2006), Nuclear First Strike: Consequences of a Broken Taboo, Baltimore, MD, USA: Johns Hopkins University Press.

Ramsey, R.P. (1962), 'The case for making “Just War” possible', in J.C. Bennett (ed.), Nuclear Weapons and the Conflict of Conscience, New York, NY, USA: Charles Scribner's Sons.

Rawls, J. (1971), A Theory of Justice, rev. edn., Cambridge MA, USA: The Belknap Press of Harvard University Press.

- (1999), The Law of Peoples, Cambridge MA, USA: Harvard University Press.

Sagan, S.D. (2004), 'Realist perspectives on ethical norms and weapons of mass destruction', in

S. H. Hashmi and S. P. Lee (eds), Ethics and Weapons of Mass Destruction: Secular and Religious Perspectives, Cambridge, UK: Cambridge University Press.

Sanger, D.E. (2009), 'Iran threatens to back out in fuel deal', New York Times, 20 October, A6. Schapiro, T. (2003), 'Compliance, complicity, and the nature of nonideal conditions', The Journal of Philosophy C(7): 329-355.

Slackman, M. (2009), 'Iran will not ship Uranium abroad, foreign minister says', New York Times. 19 November, A14.

Smith, D.D. (2006), Deterring America: Rogue States and the Proliferation of Weapons of Mass Destruction, Cambridge, UK, USA: Cambridge University Press.

Swift, A. (2007), 'The value of philosophy in non-ideal circumstances'. Seminar in Political Theory. University College London, 14 November. Retreived 26 March 2009 from http://www.ucl.ac.uk/spp/seminars/pt

Tertrais, B. (2003), 'The New Dynamics of Nuclear Proliferation', CEPS/IISS European Security Forum. Brussels, 3 March 2003. 
Tucker, R.W. (1985), 'Morality and deterrence', Ethics 95(3): 461-478.

Walzer, M. [1977] (2000), Just and Unjust Wars: a Moral Argument With Historical Illustrations, 3rd edn., New York, USA: Basic.

Way, C. (2007), 'Understanding nuclear weapons proliferation'. Institute for Global Conflict and Cooperation: Public Policy and Nuclear Threats. University of California, San Diego. Retrieved 17 July 2007 from http://igcc.ucsd.edu/PPNT.php

Wendt, A. (1999), Social Theory of International Politics, Cambridge, UK: Cambridge University Press, pp. 283-285.

Williams, M.C. (2005), The Realist Tradition and the Limits of International Relations, Cambridge, UK: Cambridge University Press. 